\title{
CERTIFICATES AS A WAY TO REGULATE FUNCTIONING OF TOURIST ENTITIES ON THE SPA \& WELLNESS SERVICES MARKET
}

\section{MAŁgorZATA JANUSZEWSKA, ${ }^{1}$ AgNiESZKA MrOCZEK-CZETWERTYŃSKA, ${ }^{2}$ ELŻBIETA NAWROCKA ${ }^{3}$}

\author{
${ }^{1}$ Wrocław University of Economics, POLAND \\ e-mail: malgorzata.januszewska@ue.wroc.pl \\ ${ }^{2}$ The Angelus Silesius University of Applied Sciences in Wałbrzych, POLAND \\ e-mail: a.czetwertynska@gmail.com \\ ${ }^{3}$ Wrocław University of Economics, POLAND \\ e-mail: elzbieta.nawrocka@ue.wroc.pl
}

KEYWORDS | certificate, SPA \& wellness services market, barriers for functioning of tourist entities

ABSTRACT

Goal of the paper is to describe certificates of hotel objects operating in the market of SPA $\&$ wellness services as a way of its functioning. This paper is based on analysis of literature, manyyears observances of the authors as well as results of questionnaires conducted in 20 SPA \& wellness objects located in Lower-Silesia health resorts. There were identified two barriers: no categorization of the SPA \& wellness objects as well as unambiguity of interpretation of law provisions regarding competences of the personnel. A way to limit them is certification which is a way to regulate functioning of the SPA \& wellness market.

\section{Introduction}

SPA \& wellness services development is related with many industries of the economy, among others, tourism, health sector, SPA cosmetics manufacture, manufacture of SPA \& wellness treatments devices, culture and general art as well as household accessories which, on the grounds of SPA \& wellness, philosophy constitute quickly growing SPA \& wellness market. 
Goal of the paper is description of certificates of hotel objects operating in the market of SPA $\&$ wellness services as a way of its functioning. Because of wide range of businesses classified as a SPA \& wellness, scientific field was limited only to services rendered by hotel objects within the tourism sector. This segment of the market is a chance to revive this industry in many fields of tourist reception, mostly in health resorts and to improve financial situation of tourist enterprises.

This paper is based on analysis of literature, many-years observances conducted by the authors as well as results of questionnaires conducted in 20 SPA \& wellness objects located in LowerSilesia health resorts. ${ }^{1}$

\section{General characteristics of the SPA \& wellness services market}

From point of view accepted in the paper in order to determine research area, the SPA \& wellness market is a segment of tourist services market (and the last one is part of general tourism market). The tourism market can be defined as a general exchangeable relations between persons and institutions announcing needs related with tourism and which have funds to pay, and persons and institutions which satisfy the needs in question for a particular fee (Rapacz, 1998, p. 10). Hence, such a defined tourism market is a main area of determination of goals regarding SPA \& wellness services, their consumption and exchange, as well as determination of actions supporting its efficient functioning including proper operation of supplying and purchasing entities.

Entities offering the SPA \& wellness services on the tourism market can be considered companies rendering professional services, based on a water and tradition of Asian cultures as well as biologic recovery devices and equipment, intended to provide client with relax, powers recovery and spiritual and mental growth of a consumer - tourist. Demanding entities/individuals are mainly women which/who desire leisure or business climate in variety of seasons but mostly during summer/winter holidays as well as extended weekends and festivals.

Market of SPA \& wellness services rendered to tourists is characterized by certain specific features in relation to other consumption markets arising from specificity of services which are subject-matter of the exchange. Among them the most important ones are ${ }^{2}$ : intangibility (no material form, a client cannot see and try before a purchase), usefulness (a purchaser can check a service - Its quality during consumption), complexity and completeness (the services in question are associated by other services e.g. night accommodation and material goods), heterogeneity (every service is unique for both, a service-provider and a consumer) and local nature (a consumer must approach a location where a service is rendered within a particular area of tourist reception). Very frequently, the services in question because of medical nature are classified as health care and SPA services. More and more frequently, services rendered by SPA \& wellness objects in the tourism market are symbolic and refer to emotional elements such as experiences and feelings. The services are, to some extent, ideas, dreams and imaginations in an awareness of a consumer. A significant

\footnotetext{
${ }^{1}$ Questionnaires were conducted by dr A. Mroczek-Czetwertyńska.

${ }^{2}$ Other properties are: higher constant cost of rendering them, limited seasonality, non-separation and no possibility to store the services.
} 
information is also share of social funds, e.g. provided by companies, to co-fund health stays in health resorts and consequent support promoting a demand for SPA \& wellness services. The aforementioned properties of the services make that final costs come close to zero and their usability/ price ratio is very unclear.

In SPA \& wellness objects there also takes place a phenomenon of higher average revenues because of packs including, e.g. accommodation, catering, biologic recovery services as well as sports and recreational services. Development of such packs is related to determination of prices for a few complementary goods. One should pay attention to the fact that prices combinations (price of a pack) in fact reduce the price competition and affect negatively a transparency of the market and they enable enterprises to overtake consumer's rent. It means that there is no full information on the market (information asymmetry) which causes large uncertainty among market participants regarding demand and supply decisions. Acc to T. DiLorenzo (2011, pp. 249-255) asymmetry of the information is the most frequently considered in a context of non-optimal allocation of resources which is caused by market inefficiency and occurrence of transactional costs. It is connected with no information or deformed information on prices and quality of a subject-matter of potential transaction on the side of a purchaser or behavior of a purchasers as a reaction to marketing actions performed by the offering party. Existence of it is related with so called moral hazard. It is a theory which states that a person/entity protected from risk can behave in a way different than it would do if it was exposed to a full risk (Dembe, Boden, 2000, p. 257). In other words, the moral hazard means situation when there appears an increase in consumption of services when distribution of a risk results in lower marginal costs of such services (Folland, Goodman, Stano, 2010, p. 153). The moral hazard causes a trust crisis on the tourism market which, in turn, promotes a system risk and hence, there is stimulated use of the market regulation mechanisms/tools.

The following circumstances of the moral hazard in the field of tourist consumption can be showed:

- surplus of consumption, e.g. excessed consumption of water, towels, cosmetics in a hotel room or over-consumption of meals and alcoholic beverages in the offer of the all-inclusive nature,

- over-consumption of health tourist services (included in a common health insurance), causes limited access (three-year waiting) for those of tourists, health condition of who would require an immediate reaction,

- great pressure on new, more effective infrastructure elements, e.g. SPA \& wellness, which frequently results in exceeded tourist absorption of a particular tourist reception area.

Generally speaking, the moral hazard stimulates negative external effects which consist in transferring of costs of over-consumption into other tourists, or costs of improperly estimated risk is transferred into other subjects of the tourism market.

Uncertainty at the side of the demand causes a risk of purchase and simultaneously - a need to counter-act of a purchaser's risk. Since information asymmetry causes unfavorable consequences for reliable entrepreneurs rendering SPA \& wellness services (negative selection) they send signals on services. Acc to signaling theory of M. Spence (1973, p. 355), entities having unverified 
information should make efforts which enable uninformed entities to form up opinions on a subject-matter of a contract. One can enumerate three groups of actions which are intended to prevent information asymmetry between a bidder and a purchaser. Every such a group of operations refers to other type of a tool meaning trust, authority or a trial (Table 1). They are intended to promote a contract between a service provider and a client. A bidder is ready to incur (costs of) them in order to reduce uncertainty of a purchaser which can persuade him/her to give up coming. To some extent, costs incurred by a bidder can be considered to be costs of advertising. A potential purchaser of SPA \& wellness services, which were partially made available, can decide not to purchase them even if a pack suits his/her preferences. It can happen since just polling of a SPA \& wellness service meets his/her needs preliminarily and he/she does not need to purchase them. Hence, application of this strategy is related to a risk of a bidder.

Table 1. Strategies of uncertainty liquidation for purchasers of SPA \& wellness services

\begin{tabular}{lll}
\hline \multicolumn{1}{c}{$\begin{array}{c}\text { Strategies of uncertainty } \\
\text { liquidation for purchaser by: }\end{array}$} & \multicolumn{1}{c}{ Circumstances and forms of a strategy } & Affection by: \\
\hline Polling & $\begin{array}{l}\text { Rendering of some of SPA \& wellness services by e.g.: } \\
\end{array}$ & Test \\
& - prizes in form of accommodation vouchers & \\
& - possibility to use single services, & Authority \\
& - advertisement. & \\
\hline Review & Review of SPA \& wellness services (SPA \& wellness hotels) by experts: & \\
& - opinions presented in a press, & Trust \\
& - loyalty programs, & \\
\hline Reputation & - opinions of visitors. & \\
\hline
\end{tabular}

Source: own work on the grounds of Kotler (2006), pp. 111-116; Varian (1998).

\section{Tendencies at the tounism mapket of SPA \& wellness sepvices - practical illustration}

Travels for health reasons into Poland has been more and more popular recently, particularly, from a moment Poland joined the EU. SPA \& wellness services market has been growing up regularly attracting tourists from more wealthy countries. However, despite serious increases (by $75 \%$ in 2013 in relation to 2012), still rate of visits for heath purposes is poor (8\%). A key one and definitely the most profitable segment in the health segment is Germany, which generates 55\% of revenues (Figure 1).

Despite relatively low expenditures a lot of Germans travel to Poland for health purposes ( $75 \%$ of this type of visits). Opposite to the Germany is Russia, citizens of which use medical and cosmetic services very rarely, however, during such visits amounts they spend per capita are much higher which, consequently, makes Russians keep 20\% share in the segment of health visits. Holland, Great Britain, Sweden and over the sea countries are next important markets (totally $18 \%$ 
share). Poles, for heath purposes also willingly participate in and constitute the most important segment of the health (recovery) tourism. Improvement or maintenance of health, as a goal of a travel in 2013, was enumerated by 4,5\% of domestic tourists (Turystyka i wypoczynek..., 2014, p. 58). One should also pay attention to the fact that average spending of Poles for health travel belongs to the highest ones in relation to other tourist goals and equals to PLN 1445.

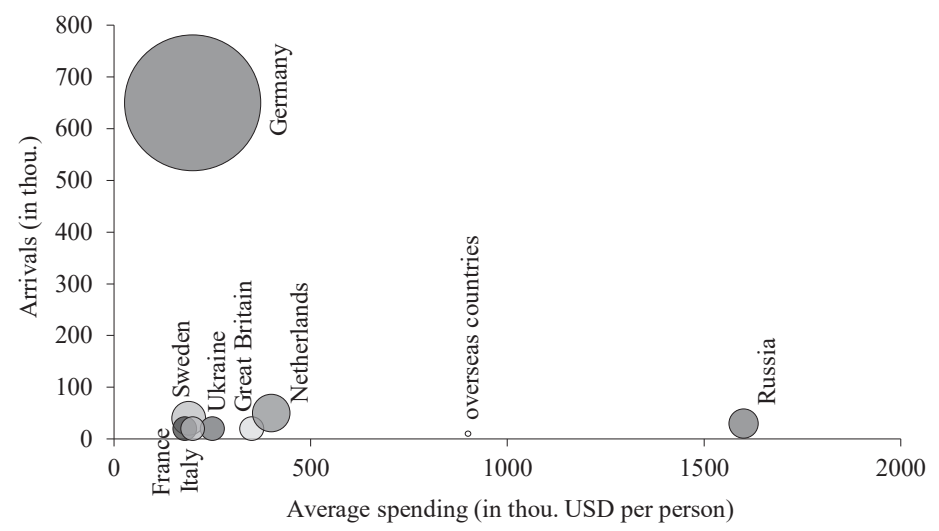

Figure 1. The most important markets in the segment of health travels into Poland.

Source: Jańczak, Patelak (2014), p. 53.

Interviews with managers and directors of hotel objects offering SPA \& wellness services enabled to identify the most substantial barriers arising from functioning of this market. In the respondent's opinion, apart from limited financial means these are mainly:

- no common and mandatory categorization of objects rendering SPA \& wellness services,

- non clear interpretation of law regulations regarding rights to perform SPA \& wellness services.

Since there are no binding categories there occurs a phenomenon of common transfer of unreliable information on attributes of SPA \& wellness services. It causes differences in services offered on the market. Objects with weaker SPA \& wellness infrastructure attract potential clients (the most frequently inexperienced ones) by attractive prices and at the same time they offer poor quality services. The second phenomenon emphasized by respondents is a misuse - by hotel objects - the SPA \& wellness term which confuses clients and makes they disagree to dishonesty of entrepreneurs. Negative phenomena existing in this market and related to disproportions between offer of SPA \& wellness hotels and objects, which offer just a few services, seem to promote implementation of necessary regulations. In the respondents' opinion they will eliminate weak entities/ objects, offer of which is not professional, and they will make order at the presently very chaotic market. More than $60 \%$ of managers of hotels offering biologic recovery emphasize justification of a system of SPA \& wellness objects categorization following law regulations regarding hotels 
and other objects rendering hotel services. The remaining respondents state that categorization will cause unnecessary growth in bureaucracy.

Other significant problems which hampers operations in this market is ambiguity regarding interpretation of legal regulations enabling to determine competences of cosmetologists and aesthetic medicine doctors as well as no regulations regarding sanitary requirements imposed on offices. Since years there has been open discussion regarding an issue whether or not a cosmetologist is entitled to perform certain treatments in SPA \& wellness hotel's treatment zone. Referring to standards of education background acquired at majors in the area of cosmetology, a person graduating from a major in question is not entitled to render health treatment services (he/she is not a person performing medical occupation) (Rozporządzenie Ministra Nauki i Szkolnictwa Wyższego... 2007). Also Polish Association of Aesthetic Medicine and Anty-Aging in 2014 published its opinion (PTMEiAA, 2014) that treatments related to issues continuity deterioration e.g. supply of a botulinum toxin or injection of implants in form of hyaluronan are healing products (Ustawa z dnia 6 września 2001 r. Prawo farmaceutyczne, 2001) and supply of them constitutes a medical service (Ustawa z dnia 15 kwietnia 2011 r. o działalności leczniczej, 2011) which can be performed by doctors only (Ustawa z dnia 5 grudnia 1996 r. o zawodzie lekarza, 1997), under circumstances necessary to render medical services. However, in fact the reality looks very different. Rules have been regularly violated and information on services is supplied to clients to a limited extent. Similar problem occurs in case of determination of competences of physio-therapists and masseurs when it comes about classifying them within a group of medial professions and acquisition of rights to render SPA \& wellness services.

\section{Certificates as a tool limiting main barpiers of functioning on the SPA \& wellness services market}

The most frequently applied certificate in Poland in the SPA \& wellness industry is Deutcher Wellness Verband. Since 1994 this association has been assessing and certifying objects in Germany and other European countries, including Poland (worth of mentioning is information that no Czech, Slovakian or Hungarian object holds such a certificate). SPA \& wellness objects can apply for 2 types of standards that is Premium-Qualitait and Special-Qualitat. First of them is awarded to hotels whose owners agree on an anonymous test based on a three-day visit of an auditor considering 750 criteria in the field of quality. If an object meets $60 \%$ of criteria it obtains a good grade ( $g u t$ ), when the result is within a range from 75 to $89 \%$, an object is awarded a very good grade (sher gut), and above $89 \%$ - it is excellent (exellent). Subject of assessment is spacious and technical infrastructure, wellness, human factor, orientation to a client, competences of employees. Subject-matter of the assessment, apart from wellness services there are also catering and hotel services. Special-Qualitat is based on 200 the most frequent criteria and certification is open. This certificate is awarded at the basis level and medical level. The audit covers catering, wellness services, professionalism of the personnel and relation of services quality to their prices (Topczewski, 2007, pp. 16-18). The certificate is valid two years. In Germany there is more than 1000 of SPA $\&$ wellness facilities and just half of them, acc to Deutcher Wellness Verband, meets minimal 
requirements. In Poland such certificates were awarded just to 5 facilities, including 3 ones belonging to Dr Irena Eris, in Wzgórza Dylewskie (exellent) in Krynica-Zdrój and Polanica-Zdrój (sher $g u t$ ), as well as to Hotel Malinowy Zdrój in Solec-Zdrój (Medical-Qualitat) and Hotel Villa Park in Ciechocinek (Basis- Qualitat).

Other appreciated certificate in Europe is Best International Health awarded from 2009 by TUV Rheinland. In 2012 the standard was based on Polish law which enables performance of proper hygiene policy and policy of safety of users of SPA \& wellness facilities in Poland. Experts developed a set of 300 criteria including, among others, surrounding of an object, SPA equipment, qualifications and experience of employees. TÜV Rheinland recommends to couple the SPA quality system with certification in the area of environment and quality management in order to acquire an integrated management strategy. Awarding of the standard takes place at 6 stages: secret audit "Secret client", review of documentation, certifying audit enabling application of the system documentation in real conditions, issuance of the certificate, audit of supervision enabling to maintain and to optimize process of improvement and renewal of the certificate.

On the basis of foreign organizations also in Poland there has been established a system of certification of hotel objects offering SPA \& wellness services and its founder is consortium of Germanischer Lloyd and Comfortum Group. Since 2008 Polish objects are awarded Spa Quality Standard certificates in 4 categories: Luxury Spa, Prestige Spa, Comfort Spa and Basic Spa. An essential idea of certification is encouraging existing objects to enhance their catalog of services constantly and to increase quality of offered SPA \& wellness services (Comfortum, 2014).

Verification is free and it takes place at two stages. First section gives consideration to minimal requirements, which result in rejection of objects, which abuse the SPA term. For objects meeting the criteria there is awarded Basic certificate. Hence, an object is entitled to use the logotype of the certificate in its promotional materials and entitles it to make efforts to get the remaining certificates. Minimal requirements from Basic level regard these elements of the offer which prove complexity of the SPA \& wellness catalog.

In an object applying for a certificate there is conducted an audit. It is a multi-stage operation based on previously prepared factors, auditors' opinion and results of review of documents. On such basis the Comfortum Group makes a decision on awarding of a certificate with determination of its level: Comfort, Prestige and Luxury. Additionally, there can be prepared a list of tasks which a facility must meet to get a higher standard. Also this certificate is awarded for 2 years.

The certification is complex and it means it is impossible to get a certificate just for a part of SPA \& wellness, when nigh accommodation services or catering services do not meet required conditions. In 2015 just 11 hotels in Poland got this certificate. Basic certificate was awarded to: Hotel Zamek na Skale - Lądek-Zdrój, Hotel Szablewski - Środa Wielkopolska, Hotel Lubicz - Ustka, Hotel Jelenia Struga Resort SPA - Kowary, and Prestige: Willa Hoff Wellness \& SPA - Trzęsacz, Malinowy Dwór hotel Spa - Świeradów-Zdrój, Hotel Medi SPA Biały Kamień - Świeradów-Zdrój, Hotel Diament - Ustroń, Hotel Natura Residence - Siewierz, Hotel Malinowy Zdrój - Solec-Zdrój and Kormoran Wellness Medical Spa - Rowy. 
Apart from certificates which objects with SPA \& wellness may apply for, there are awarded prizes for the best entities. As an example one can mention a contest under the name Prestige Spa Awards organized by Comfortum Group, a Best Hotel Award contest by Polish Tourism Organization as well as prizes awarded by websites - Booking.com, TripAdvisor.com, etc.

One should notice that a small number of entities renew previously obtained certificates. It can be a result of high costs of the procedure (e.g. audit Deutcher Wellness Verband exceeds EUR 2 thousand) and long-lasting procedure which hampers customer service and makes personnel overloaded. In order to identify real reasons there were conducted phone talks with five managers of enterprises, which did not renew the certificates. It turned out that main reason for giving up of the previously awarded standard there were disproportionate incurred financial means and organizational efforts in relation to obtained market effects. They mentioned they expected advantages within a short time in order to satisfy German travel agencies and German tourists. Moreover, evolution of promotion strategy resulted from ownership changes or changes of structure of tourists visiting the SPA \& wellness objects under examination.

\section{Conclusions}

From afore-described surveys it results that many objects, which have been leaders of the hotel objects in Poland, also have certificates confirming quality of their SPA \& wellness services. Special attention should be paid to objects of Dr Irena Eris that is hotels - Malinowy Zdrój and Malinowy Dwór.

It seems that in situation of no clear and common categorization of the objects of SPA \& wellness nature, described certificates constitute a signal of high quality of rendered services in the biological recovery objects and consequently, they limit risk of a client. Because of number of criteria regarding social factors, previously described certificates also liquidate negative impact of unambiguity of provisions regarding skills of personnel and functioning on the market. Classifications of SPA \& wellness objects are based on varied criteria and their assessment causes a chaos in terms of interpretation of results of accreditation. Certificate awarding by private associations and organization generates high costs of obtaining and fulfillment of business groups' goals instead of social goals. From interviews it results that objects, which hold certificates, observe great growth of acknowledgment in the market and respect of the entities as well as great growth in revenues from business. It means that awarding of prizes to objects and acquisition of certificates by entities is advantageous for them and for their clients. Implementation of certificates enables proper regulation of SPA \& wellness services market because of leveling of information asymmetry and limitation of a negative selection.

\section{Reíerencess}

Comfortum (2014). Certyfikacja obiektów SPA \& WELLNESS. Available at: http://spa-certyfikat.pl/wp-content/uploads/2014/05/podrecznik_certyfikacyjny.pdf (1.03.2016).

Dembe, A.E., Boden, L.I. (2000). Moral Hazard: A Question of Morality? New Solutions, 10 (3), 257-279. 
DiLorenzo, T. (2011). A Note on the Canard of "Asymmetric Information" as a Source of Market Failure. The Quarterly Journal of Austrian Economics, 14 (2), 249-255.

Folland, Sh., Goodman, A.C., Stano, M. (2010). The economics of Health and Health Care. Boston (MA): Prentice Hall. Jańczak, K., Patelak, K. (2014). Zagraniczna turystyka przyjazdowa do Polski w 2013 roku. Łódź: Activ Group.

Kotler, P. (2006). Kotler o marketingu. Jak tworzyć, zdobywać i dominować na rynkach. Gliwice: Wydawnictwo Helion.

Ordinance of the Minister of Science and Higher Education dated 12.07.2007 on education standards for particular majors and levels of education as well as establishing and terms and conditions which a school/university must meet to conduct inter-major studies and macro-majors, Journal of Acts no. 164, item 1166.

PTMEiAA (2014). Stanowisko PTMEiAA w sprawie wykonywania zabiegów lekarskich z zakresu medycyny estetycznej przez osoby nieuprawnione. Available at: http://www.ptmeiaa.pl/wiadomosci/komunikaty/stanowisko-ptmeiaaw-sprawie-wykonywania-zabiegow-lekarskich-z-zakresu-medycyny-estetycznej-przez-osoby-nieuprawnione (1.03.2016).

Rapacz, A. (ed.) (1998). Przedsiębiorstwo turystyczne na rynku. Wrocław: AE we Wrocławiu.

Rozporządzenie Ministra Nauki i Szkolnictwa Wyższego z dnia 12.07.2007, w sprawie standardów kształcenia dla poszczególnych kierunków oraz poziomów kształcenia, a także trybu tworzenia i warunków, jakie musi spełniać uczelnia, by prowadzić studia międzykierunkowe i makrokierunki (2007). Dz.U.164.1166.

Spence, M. (1973). Job Market Signaling. Quarterly Journal of Law and Economics, 87 (3). Available at: http://www-bcf. usc.edu/shaddin/cs590fa13/papers/jobmarketsignaling.pdf.

Topczewski, A. (2007). Niemieckie standardy w Polsce. Spa Business, 3 (05), 16-18.

Turystyka i wypoczynek w gospodarstwach domowych w 2013 roku (2014). Warszawa: Główny Urząd Statystyczny.

Ustawa z dnia 15.04.2011 o działalności leczniczej, Dz.U. 2011.112.654.

Ustawa z dnia 5 grudnia 1996 r. o zawodzie lekarza (1997). Dz.U. 1997.28.152.

Ustawa z dnia 6.09.2001, Prawo farmaceutyczne (2001). Dz.U. 2001.26.1381.

Varian, H.R. (1998). Market for Information Goods. Available at: http://people.ischool.berkeley.edu/ hal/Papers/japan/ japan.html (1.03.2016).

\section{CERTYFIKATY SPOSOBEM REGULACJI FUNKCJONOWANIA PODMIOTÓW TURYSTYCZNYCH NA RYNKU USŁUG SPA I WELLNESS}

SŁOWA KLUCZOWE

STRESZCZENIE certyfiakt, rynek usług SPA \& wellness, bariery funkcjonowania podmiotów turystycznych

Celem artykułu jest zaprezentowanie wyników analizy certyfikacji obiektów hotelarskich na rynku usług SPA i wellness jako sposobu regulacji jego funkcjonowania. W artykule wykorzystano analizę literatury, wieloletnią obserwację własną autorek i wyniki wywiadu kwestionariuszowego przeprowadzonego w 20 obiektach SPA i wellness zlokalizowanych w dolnośląskich uzdrowiskach. Zidentyfikowano dwie główne bariery: brak kategoryzacji obiektów SPA i wellness, a także niejednoznaczność interpretacji przepisów dotyczących kompetencji personelu. Sposobem na ich ograniczanie jest certyfikacja będąca sposobem regulacji funkcjonowania rynku usług SPA i wellness. 